\title{
THE FIRST TEN SYMPOSIA ON EARLY/LOWER VERTEBRATES
}

\author{
(1967-2004)
}

\begin{abstract}
HANS-PETER SCHULTZE
Institut für Paläontologie, Museum für Naturkunde, Humboldt-Universität zu Berlin, Invalidenstr. 43D-10115 Berlin, Germany. Present address: 2001 Vermont St. Lawrence, Kansas 66046, USA.vrtpaleo@ku.edu
\end{abstract}

\section{INTRODUCTION}

Palaeoichthyology began with Louis Agassiz in the first half of the 19th century. His monumental work on fossil fishes (Agassiz, 1833-1844) was succeeded by Woodward's catalogues $(1889,1891,1895,1901)$ of the fossil fishes of the British Museum (Natural History), London. Woodward compiled knowledge of fossil fishes at the time, gave synonymy lists, diagnoses of taxonomic units and systematic arrangements of larger groups. His work was very influential over many years and is still an important source of information. At that time fossils were not treated like living organisms, they were described and compared on the basis of external features such as shape, body proportions, sculpture and number of elements.

E. Stensiö changed that approach. He considered fossils as animals embedded in rocks, as for example extant forms enclosed in paraffin. In 1916, a young graduate student, Erik Andersson, had so impressed A. S. Woodward in London with his approach, that he, now known as E. A:son Stensiö, was subsequently offered the opportunity to study the cephalaspids from Great Britain deposited in the British Museum (Natural History). He published many monographs on the anatomy of lower vertebrates such as cephalaspids, placoderms and actinopterygians, and acquired a large group of followers and disciples in Sweden and abroad, the so-called "Swedish school," characterized by both detailed anatomical descriptions and comparisons with extant forms. Phylogeny through time played a secondary role in their thinking. The goal was to construct a "Grundbauplan" for each group that should include all features that had ever appeared in the group: the approach of the ideal morphologists of the 19th century. From the 1930's into the 1960's Stockholm was the center of palaeoichthyology (Figure 1). It was only natural that E. Stensiö should be honoured with a Nobel Symposium in 1967.
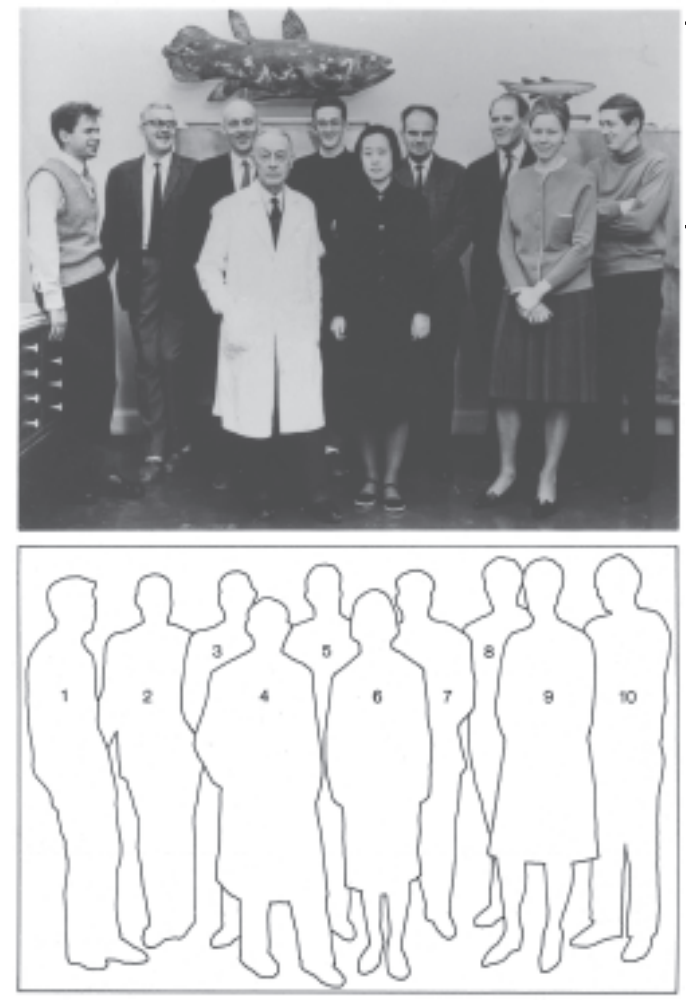

Figure 1. Staff and guests of the Palaeozoologiska Afdelningen, Naturhistoriska Riksmuseet, Stockholm, Sweden, in January 1967. 1. H.-P. Schultze; 2. T. Ørvig;; 3. H. Bjerring; 4. E. Stensiö; 5. G. Nelson; 6. Chang Mee-mann; 7. R. Thorsteinsson; 8. E. Jarvik; 9. E. Mark-Kurik; 10. H. Jessen (photo by U. Samuelson, Stockholm).

At the Nobel Symposium the great figures of palaeoichthyology were united: R. H. Denison, D. L. Dineley, W. Gross, A. Heintz, E. Jarvik, J.-P. Lehman, E. Nielsen, O. Nybelin, D. V. Obruchev, T. Ørvig, B. Schaeffer, E. A:son Stensiö, E. I. White, and R. Zangerl. In addition, some young palaeoichthyologists were present: S. Mahala Andrews, S. E. Bendix-Almgren, H. C. Bjerring, N. Bonde, D. Goujet, H. L. Jessen, R. S. Miles, G. J. Nelson, Y. Pageau, C. Patterson, A. Ritchie, H.-P. Schultze, Barbara Stahl, K. S. Thomson, and Emilia I. Vorobyeva. As was common at the time, all these scientists were from the northern hemisphere and had wide reaching international connections, but representatives from the southern continents and China were missing even though E. Stensiö had good relationships with the Chinese embassy. Australia, however, was represented by the director of the Zoological Garden in Sydney, R. Strahan, who supported 
Stensiö's idea of the diphyly of the cyclostomes. Later, a symposium of the Linnean Society (1976) was dedicated to E. A:son Stensiö, and in addition to his most successful student, E. Jarvik. Only during the symposium in Tallinn 1976, the idea was born to hold these symposia on a more regular basis.

\section{SEQUENCE OF SYMPOSIA, MAIN GOALS AND ACHIEVEMENTS}

\section{1967- NOBEL SYMPOSIUM IV: Current Problems of Lower Vertebrate Phylogeny}

Stockholm, Sweden, June 12-16, 1967 (to honour Erik Stensiö) with 47 participants: 13 Sweden, 8 USA, 7 Great Britain, 3 Denmark, 3 France, 2 Germany, 2 Norway, 2 Russia, 2 Canada, 2 Australia, 1 Israel, 1 Poland, 1 Belgium (18 presentations). Field trip: Linné's garden in Uppsala and Linné's Hammarby residence. Proceedings: Ørvig, T. (ed.) 1968. (28 papers). First encounter with cladistics (L. Brundin).

In 1967 the first symposium was dedicated to celebration of the life-long contributions to research on lower vertebrates by E. A:son Stensiö. All participants, with the exception of L. Brundin, gave detailed morphological descriptions for which the "Swedish school" was famous, and argued for homology and relationships based on general similarities. Nevertheless, most participants had their first encounter with Hennig's phylogenetic principles during this event. R. Zangerl, translator of Hennig's 1950 book (Hennig, 1966), L. Brundin, a promoter of Hennig's ideas, and G. J. Nelson who was introduced to Hennig's phylogenetic method by L. Brundin and became thereafter the strongest promoter of Hennig's principles, were present. Before the banquet and subsequently in the proceedings L. Brundin, an entomologist of the Naturhistoriska Riksmuseet, Stockholm, gave a presentation on the application of Hennig's phylogenetic principles (Brundin, 1968). This had no impact on the other presentations subsequently published in the proceedings (Ørvig, 1968).

For instance, Stensiö (1968) derived myxinoids from heterostracans, and petromyzontids from more primitive cephalaspidomorphs than the known cephalaspidomorphs, on the basis of reconstructions of soft tissue anatomy, thus arguing for a diphyletic origin of cyclostomes. Nelson (1968) favoured a close relationship between acanthodians and elasmobranchiomorphs based on a comparison of gill arch structures, whereas Miles (1968), using different features, saw a relationship of the acanthodians with bony fishes. Patterson (1968) placed helodont, cochliodont and menaspoid bradyodonts with chimaeroids in the Holocephali, whereas Bendix-Almgren (1968) could not find indications of a direct link between bradyodonts and chimaeroids. Schaeffer (1968) gave arguments in favour of a unitary Osteichthyes including Actinopterygii, Crossopterygii and Dipnoi as did Denison (1968) and Bertmar (1968), whereas Jarvik (1968a, b) placed the dipnoans closer to elasmobranchiomorphs. Thomson (1968) dismissed the idea of the diphyly of tetrapods, whereas Lehman (1968) could not find enough support in details of the tooth structure to dismiss this proposal. At the end of the proceedings, Jarvik (1968b) presented a scheme showing the history of vertebrates but without indicating any relationships ("isolated groups"). He argued that the common ancestors of different vertebrate groups were to be found in the Cambrian and Precambrian because of the slow speed of change during evolution from the Devonian to the present. In his contribution, Zangerl (1968: figs 15-17) showed bone cells in the scales of the elasmobranch Holmesella in unretouched photographs, whereas these are not evident in figures of Holmesella published by Ørvig (1966). Today, digital photography gives the possibility to change a picture
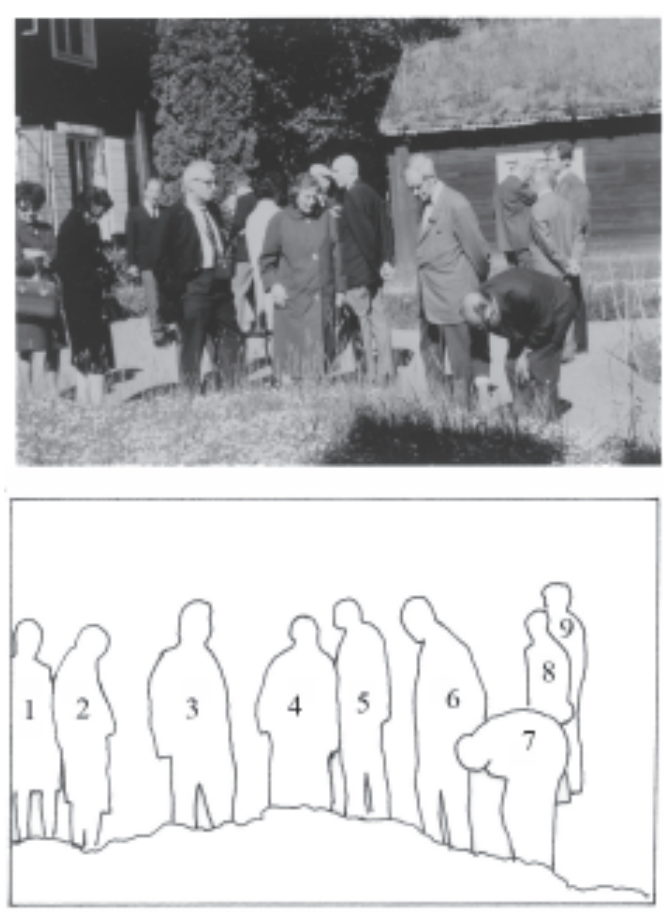
without leaving traces of these changes. In Stockholm, this was done by retouching photographs by hand.

A visit to the former residence of C. Linné (Uppsala and Hammarby, Figure 2) provided a good demonstration of the need for stable classification.

2. Linnean Society Symposium - Interrelationships - of Fishes. London, Great Britain, June 27-28, 1972. Arranged in honour of Professors E. A. Stensiö and E. Jarvik, Stockholm with 59 participants: 43 Great Britain, 4 Sweden, 4 Denmark, 3 USA, 1 France, 1 Germany, 1 Norway, 1 Nigeria, 1 Tanzania (14 presentations). Proceedings: Greenwood, P. H., Miles, R. S. \& Patterson, C. (eds) 1973. (15 papers). "Modern" approach in phylogeny especially for actinopterygians (neopterygians and teleosts).

In 1972, the second symposium was organized by the Linnean Society of London to honour E. A:son Stensiö and E. Jarvik for their outstanding contributions to the description

Figure 2. Hammarby, the residence of Linné near Uppsala: 3. D. Stahl; 4. Mrs. Heintz; 5. H. C. Bjerring; 6. A. Heintz; 7. D. V. Obruchev; 8. W. Gross; 9. H.-P. Schultze. 
and interpretation of fossil vertebrates. Nevertheless, times had changed. G. J. Nelson had pushed strongly for the application of Hennig's approach during the years since 1967 and the second symposium was held in a completely different atmosphere. By contrast to the first symposium, and to the "Swedish school," establishing relationships within and between groups based on synapomorphies was the main goal of the second symposium. The presentations at this meeting followed the modern approach of using Hennig's principles to establish phylogenetic relationships. A diagrammatic scheme of sister group relationships can be found in more than one half of the contributions to the proceedings (see Greenwood et al., 1973). Compagno (1973) presented the first phylogenetic scheme for extant Euselachii, whereas Zangerl (1973) continued to present developmental levels (grades) through time. Miles (1973) tested his 1968 proposal that the acanthodians are the sister group of the osteichthyans, a relationship supported by Gardiner (1973), who also argued, in the same volume, for a division of osteichthyans into actinopterygians and sarcopterygians (Crossopterygii + Dipnoi). Andrews (1973) divided the Crossopterygii into two groups based on details of the skull roof pattern: Quadrostia (Onychodontiformes, Osteolepiformes + Rhizodontiformes) and Binostia (Actinistia + Porolepiformes). This division is very unusual and subsequently has only been reproduced by Zhu \& Schultze (2001), where Porolepiformes and Actinistia are the subsequent basal groups within the "Crossopterygii." By contrast, Bjerring (1973) identified the actinistians as a separate group "remote from other groups of gnathostome craniates" (p. 200). Schaeffer (1973) attempted the first phylogenetic arrangement of primitive actinopterygians, with acipenserids and their close relatives at the base of the cladogram, whereas Jessen (1973) argued for a closer relationship of acipenserids with teleosts. The most important papers were those on the interrelationships of teleosts and neopterygians; they became the framework for phylogenetic research on these groups that has persisted up to the present day. The investigation of the interrelationships of neopterygians by Patterson (1973) is a classic example of how questions of interrelationship should be approached. The contributions by Greenwood (1973), Roberts (1973) and Rosen (1973) present relationship schemes based on character analysis for different teleostean groups.

3. International Colloquium on Middle Palaeozoic Fishes. Tallinn, USSR (Estonia), September 28-30, 1976 with 35 participants: 15 Russia, 5 Estonia, 4 France, 2 Sweden, 2 Latvia, 2 Australia, 2 Great Britain, 1 Norway, 1 Lithuania, 1 Germany (26 presentations). No proceedings. Discussion of homology of skull roof bones: T. S. Westoll, E. Jarvik, M. A. Shishkin, E. I. Vorobyeva, N. S. Lebedkina, and H.-P. Schultze.

Reports on descriptions and the biostratigraphy of vertebrates from the Ordovician to the Triassic were presented at the third symposium in 1976 (Figure 3). The modern approach of the second symposium was not followed. For instance, Jarvik compared structures of extant sharks with those of acanthodians in his traditional approach and concluded that sharks and acanthodians are closely related (Jarvik, 1977). A round table including T. S. Westoll, E. Jarvik, M. A. Shishkin (Figure 4), E. I. Vorobyeva, N. S. Lebedkina and H.-P. Schultze centered on the discussion of the homology of skull roofing bones in osteichthyans and specifically in sarcopterygians. M. A. Shishkin (see Shishkin, 1973) favored Westoll's homologies (Westoll, 1943) and rejected postulated homologies of the skull roofing bones in temnospondyls and osteolepiforms by Jarvik (1967). He also contradicted N. S. Lebedkina, who referred to extant actinopterygians, because according to Shishkin it was not certain that the names of the skull roofing bones of teleosts were correctly homologized with those of tetrapods. Jarvik referred to comparisons between the extant frog and the fossil Eusthenopteron and raised doubts on all phylogenetic connections as the basis for homologization. Jarvik followed the approach of the "Swedish school," that is, homology not by common ancestry but by similarity only. Westoll's homologization is still accepted today (e.g. Jollie, 1962; Schultze, 1993; Janvier, 1996) but only with

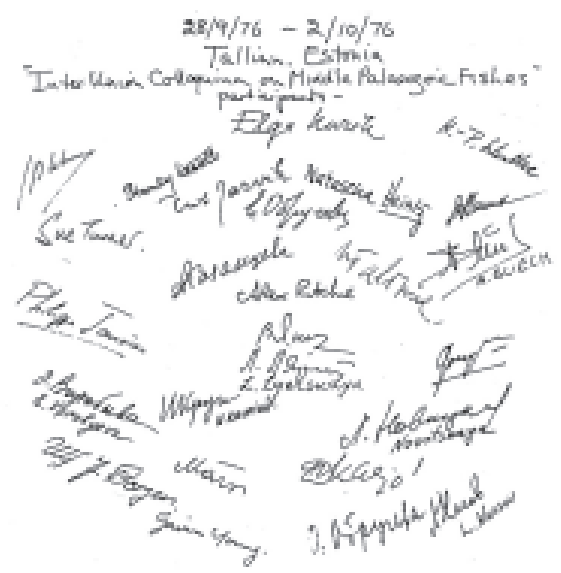

Figure 3. Signatures of participants of the third symposium in Tallinn 1976: Elga Kurik, H.-P. Schultze, J.-P. Lehman, Stanley Westoll, Erik Jarvik, Natascha Heintz, E. Klaamann, E. Obrucheva, Sue Turner, A. Kasantseva, V. Karatajuté-Talimaa, A. Ritchie, P. Janvier, V. Yakovlev, L. Lyarskaya, D. Goujet, E. Vorobyeva, N. Krupina, L. Novitskaya, Märss, D. Kaljo, Ulf J. Borgen, Gavin Young, O. Obrucheva, L. Nessov (collected by A. Ritchie).

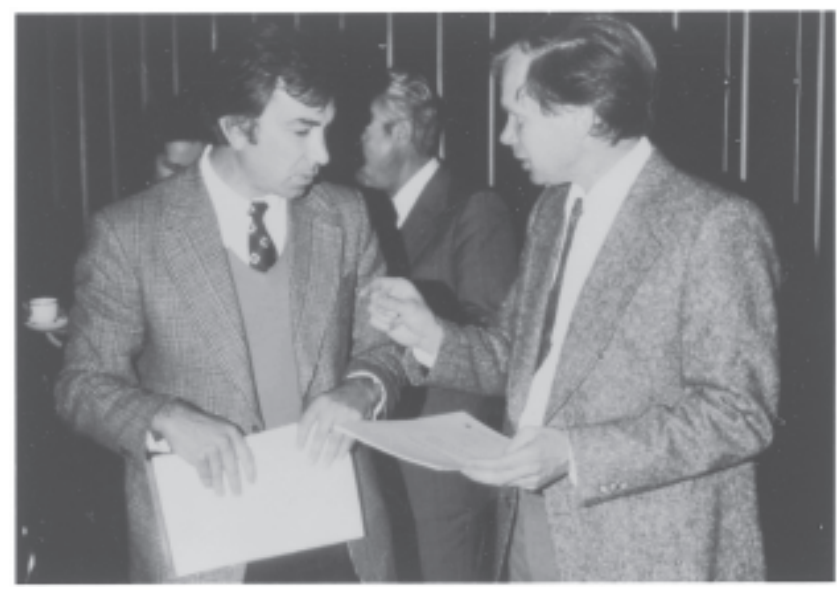

Figure 4. M. A. Shishkin and H.-P. Schultze at the third symposium in Tallinn 1976. 


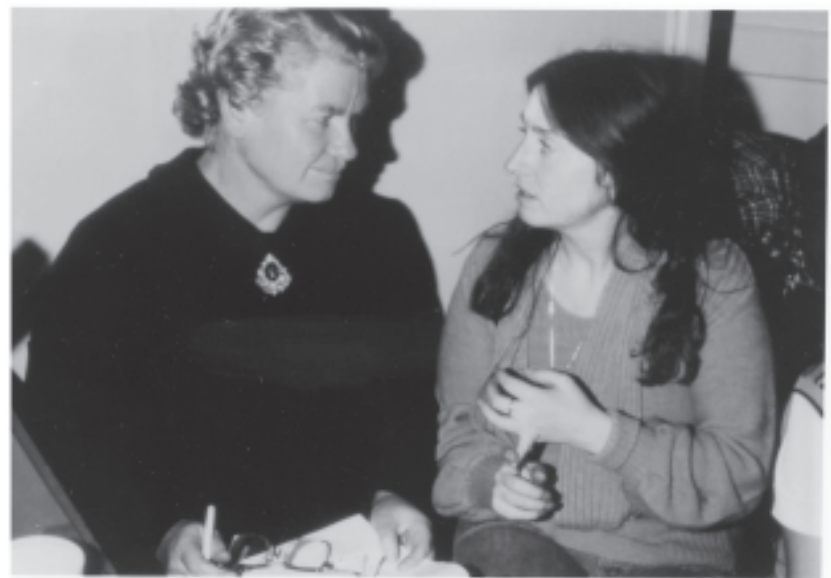

Figure 5. V. Karatajuté-Talimaa and S. Turner in a discussion concerning thelodonts at the third symposium in Tallinn 1976. reservations by ichthyologists studying actinopterygians, who favor tradition as a means of achieving a "stable" terminology.

Palaeoichthyologists from the East (V. Karatajuté-Talimaa, T. Märss) and the West (A. Blieck, S. Turner) (Figure 5), studying vertebrates as stratigraphic markers, met for the first time and started to discuss the importance of this type of material for biostratigraphy, a "byproduct," after Gross, of careful work on the histomorphological features of microvertebrates.

\section{Symposium on the Evolution and Biogeography of Early} Vertebrates. Sydney and Canberra, Australia, February 1626, 1983 with 22 participants: 8 Australia, 4 Great Britain, 3 China, 3 USA, 2 France, 1 Estonia, 1 Russia. Field trips: 1. Devonian localities in the Forbes/Grenfell area, N.S.W.; 2. Devonian localities in the Braidwood and Wee Jasper area,

N.S.W.; 3. Devonian localities in the Cobar region, N.S.W. (28 presentations). Proceedings: Campbell, K. S. W., Ritchie, A., Warren, J. W. \& Young, G. C. (eds) 1984 (14 papers).

In 1983, the fourth symposium started in Sydney and continued in Canberra, Australia. It included the biogeography of early vertebrates for the first time, but only G. C. Young dealt with the subject. He introduced vicariance biogeography based on cladograms (Young, 1984). At the time, this was not strictly new anymore, but the approach was still not used in early vertebrate research. Papers on the biostratigraphy of vertebrates, the interrelationships of different groups and the description of new forms were presented (Campbell et al., 1984). For the first time the wealth of Australian Palaeozoic fishes was showcased by a very active Australian group of palaeoichthyologists (Figure 6). The majority of papers dealt with placoderms. Goujet (1984a) presented a new scheme for the interrelationships of placoderms, in which the antiarchs did not form the closest relatives of the arthrodires, as in earlier relationship schemes. The more basal placement of antiarchs compared to arthrodires within the placoderms is now accepted (Goujet \& Young, 1995; Goujet, 2001). Papers on dipnoans came second in terms of number of presentations. Campbell \& Barwick (1984) demonstrated that the posterior internal nasal opening of dipnoans could not be homologized with the choana of tetrapods (contra Rosen et al., 1981). A new osteichthyan from the Lower Devonian of China, Diabolepis (described first as Diabolichthys by Chang \& Yu, 1984), was presented as an early lungfish still with two external nasal openings. This fish stirred up a lot of controversy at the symposium and during the following years.

The field trips were an integral part of the symposium, during the move from Sydney to Canberra (Figure 7) and after the symposium. It was therefore of advantage that the number of participants was small so that effective discussions could take place, especially on the palaeoenvironment of the Red Beds. "They are continental as is written in good textbooks" (K. S. W. Campbell, personal communication to A. Blieck and D. Goujet).

5. The Symposium on Early Vertebrate Studies and Related Problems in Evolutionary Biology. Fangshan near Beijing, and Kunming, China, September12- 26, 1987 with 42 participants: 19 China, 5 USA, 5 Australia, 4 Great Britain, 4 France, 2 Norway, 1 Canada, 1 Denmark, 1 Russia (34 presentations). Field trips: 1. Peking man locality at Choukoutien; 2. Chinese wall, Ming tombs and Forbidden City; 3. Devonian localities near Wuding, Qujing and Kunming, Yunnan province. Proceedings: Chang Mee-mann, Liu Yu-hai \& Zhang Guo-rui (eds) 1991 (21 papers).

After the cultural revolution, Chinese palaeontologists became very active in collecting and publishing on new discoveries, e.g. of Devonian fish fossils. The fifth symposium in 1987 was the first opportunity for most of the participants from the West to meet a younger generation of Chinese palaeoichthyologists (Figure 8) and to visit the Devonian localities in southern China. Half of the presentations (and papers published in the proceedings: Chang et al., 1991) were on Chinese Devonian fishes with one on Chinese Permian fish. This symposium gave the first glimpse of the importance of Chinese Early Devonian vertebrates, that was to come in the following years, including Diabolepis, which had already created controversies at the 1983 symposium in Australia. Indirectly, Campbell \& Barwick (1991) opposed the relationship of Diabolepis with dipnoans, because they argued for secondary appearance of teeth (denticles) in dipnoans. Thus they also opposed Denison (1968) who had already considered denticulation as primitive for dipnoans at the first symposium. Young (1991) described the first armored agnathan vertebrate from the Devonian of Australia, preserved only as a mold; H.-P. Schultze argued for similarities with arthropods. One paper on the caudal skeleton of teleosts and the interrelationships of this group (Arratia, 1991) dealt with a relatively young, and very different group of fishes than all the other papers, and became a widely cited paper among ichthyologists studying teleosts. Like Arratia (1991), half of the authors used Hennig's principles to establish interrelationships. The researchers on microvertebrates joined in the spirit of the 1976 symposium and decided to begin a cooperative project. S. Turner pushed forward the idea and started a newsletter (Ichthyolith Issues) in 1988. 

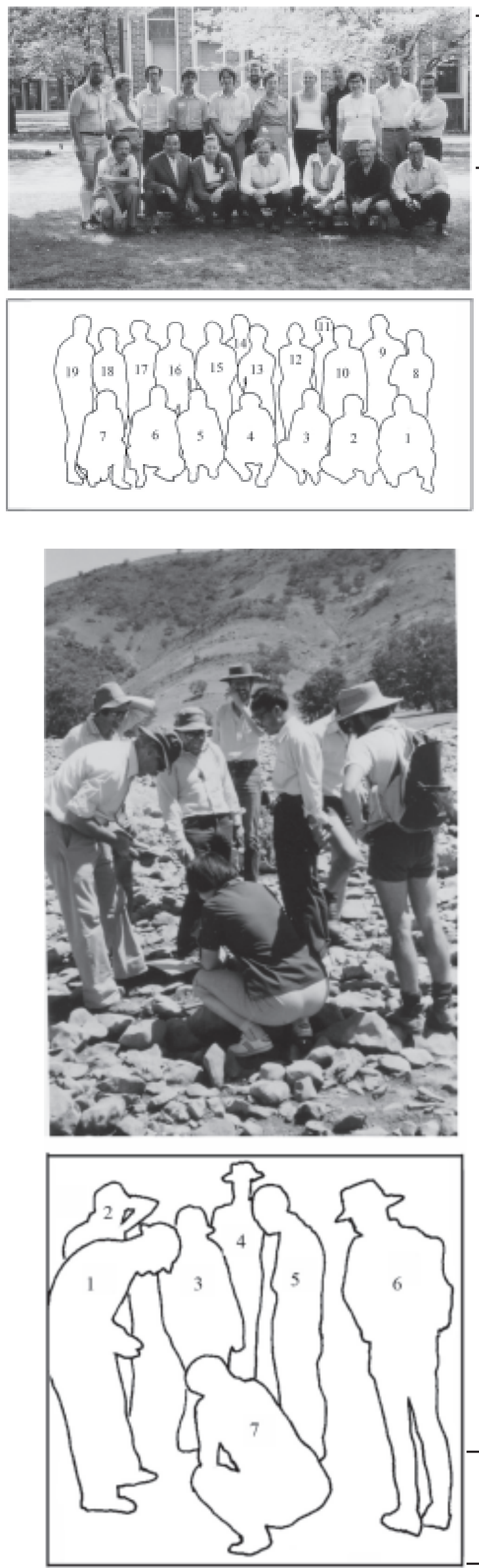

Figure 6. Participants of the fourth symposium in Canberra 1983: 1. Wang Nian-zhong; 2. R. E. Barwick; 3. Chang Mee-mann; 4. H.P. Schultze; 5. E. Mark-Kurik; 6. Pan Jiang; 7. R. Lund; 8. D. Goujet; 9. K. S. W. Campbell; 10. S. M. Andrews; 11. J. Warren; 12. A. Kemp; 13. E. I. Vorobyeva; 14. B. Jones; 15. J. A. Long; 16. C. Marshall; 17. P. L. Forey; 18. M. M. Smith; 19. A. Ritchie.

During the symposium, which was held in Fangshan near Beijing Chinese colleagues presented aspects of Chinese culture ranging from Choukoutien (Peking man) to the Forbidden City. Several important Devonian localities in Yunnan (Figure 9) were visited. In Yunnan, during the field trip, there were many discussions concerning the age and correlation of the strata around the Silurian-Devonian boundary.

6. $2^{\text {nd }}$ International Colloquium on the Middle Palaeozoic Fishes. Tallinn, Estonia, September 12-18, 1989 with 62 participants: 18 Russia, 8 Estonia, 5 Latvia, 5 Great Britain, 5 USA, 4 France, 3 China, 3 Lithuania, 2 Germany, 2 Sweden, 1 Canada, 1 Belarus, 1 Ukraine, 1 Australia, 1 Netherlands, 1 Norway, 1 Poland (32 presentations +13 posters). Field trip: Silurian of Saaremaa and Devonian of southern Estonia and northern Latvia. Proceedings: Mark-Kurik, E. (ed.) 1992 (29 papers).

The " $2^{\text {nd }}$ International Colloquium on the Middle Palaeozoic Fishes" in Tallinn was proposed for 1989, even though the next symposium on early vertebrates was planned for 1991 in Miguasha, Canada, during the symposium in China. Still the symposium in Tallinn was accepted as follow-up symposium of the fifth symposium.

The symposium in Tallinn in 1989 took place at a time of great political changes in eastern Europe. The 50th anniversary of the Molotov-Ribbentrop pact, which dismantled the Baltic States, was commemorated at many sites in the town. Baltic and Russian colleagues who were not able to attend the symposia in Australia and China, were present in great numbers and young students of palaeoichthyology from many different countries also appeared (Figure 10). As a change, talks (and papers in the proceedings, Mark-Kurik, 1992) were arranged by subject and not in the usual systematic order from agnathans to tetrapods. More than half of the talks and posters described new forms, or dealt with their relationships (e.g. Valiukevicius, 1992); less than one third discussed palaeoenvironments (e.g. Kurss, 1992), a subject preferred by the Baltic colleagues because of the availability of a dense network of borehole records; and only one fifth of the talks dealt with functional morphology (e.g. Vorobyeva $\&$ Kuznetsov, 1992). In the proceedings (Mark-Kurik, 1992), the division into subjects (palaeoecology: 8 papers; functional morphology: 5 papers; morphology, ontogeny and

Figure 7. Participants of the field trip to Early Devonian outcrops at Burrinjuck Dam, New South Wales, during the fourth symposium 1983: 1. K. S. W. Campbell; 2. P. L. Forey; 3. D. Goujet; 4. A. Blieck; 5. Wang Nian-zhong; 6. lan Stewart; 7. Chang Mee-mann. 

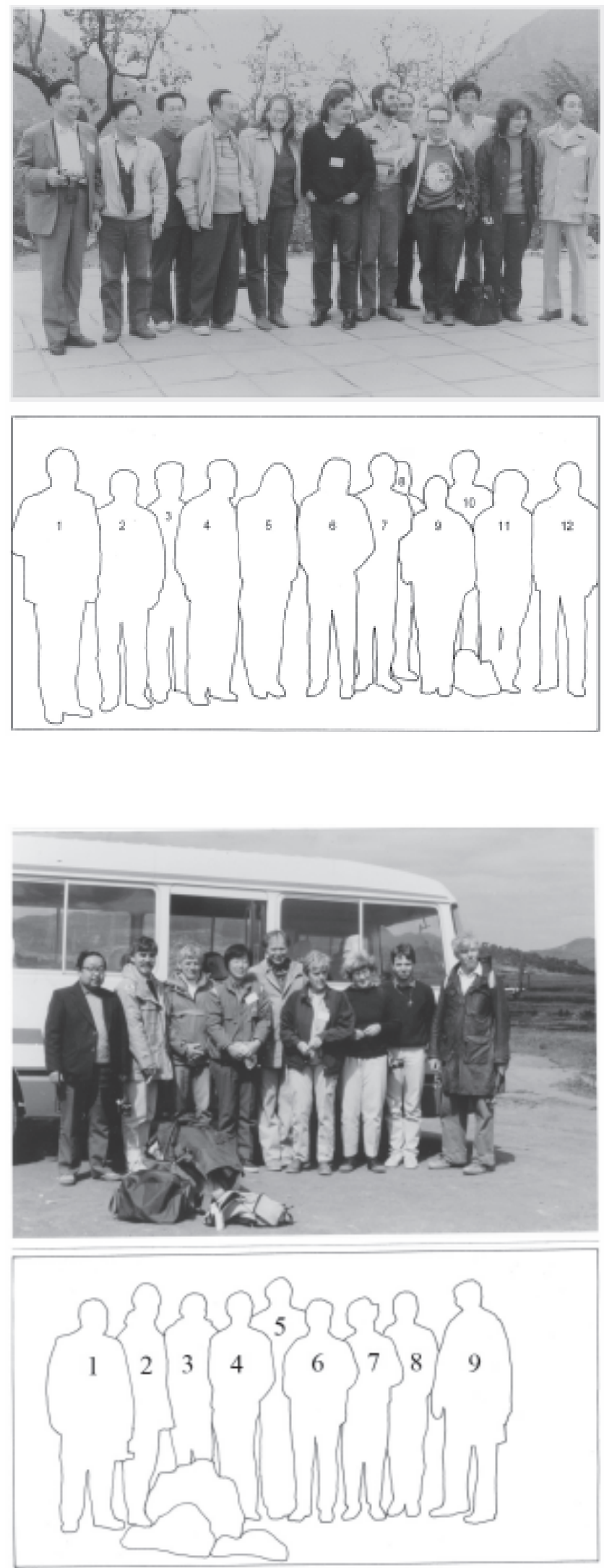

Figure 9. The sarcopterygian group near Xitun, west of Qujing, Yunnan (field trip of the fifth symposium 1987): 1. Song Chang-qi; 2. M. Arsenault; 3. R. E. Barwick; 4. Chang Mee-mann; 5. H.-P. Schultze; 6. M. M. Smith; 7. S. M. Andrews; 8. R. Cloutier; 9. K. S. W. Campbell.
Figure 8. Group picture with Chinese palaeoichthyologists during the fifth symposium 1987: 1. Zhang Guo-rui; 2. Lee Cho Min; 3. Wang Jun-qing; 4. Pan Jiang; 5. K. Dennis-Bryan; 6. H. Lelièvre, Wang Shi-tao behind Lelièvre; 7. G. C. Young; 8. Lui Shi-fan; 9. D. Goujet; 10. Zhu Min; 11. V. T. Young; 12. Liu Yu-hai.

relationships: 10 papers; environment and fish assemblages: 6 papers) was followed more strictly.

In contrast to the symposium in 1976 in Tallinn, field trips were possible on this occasion. The Devonian in southern Estonia and in Latvia, including the house where W. Gross grew up (Schultze, 1996, Figure 1) and started to collect fossil fishes as a schoolboy, and the Silurian of Saaremaa (Ösel) were visited.

$7^{7 .} 7^{\text {th }}$ International Symposium Studies of Early Vertebrates. Parc de Miguasha, Quebec, Canada, June 9-22, 1991 with 58 participants: 14 Canada, 10 Great Britain, 8 USA, 6 France, 5 Russia, 4 Australia, 3 Germany, 2 China, 2 Sweden, 1 Estonia, 1 Lithuania, 1 Italy, 1 Netherlands (41 presentations). Field trips: 1. Silurian and Devonian of Gaspé peninsula, Quebec; 2. Carboniferous of New Brunswick and Nova Scotia. Proceedings: Arsenault, M., Lelièvre, H. \& Janvier, P. (eds) 1995 (20 papers). Development of the fossil fish site, new building (1999: World heritage site).

The director of the Parc de Miguasha, M. Arsenault, used the symposium to successfully obtain new buildings for the park, so the seventh symposium, held in 1991, could take place in the newly finished lecture hall. Arsenault was also able to convince E. Jarvik, then aged 83 (Figure 11), to attend one more symposium on early vertebrates having last taken part in 1976. Eusthenopteron foordi, the best described fossil fish (Jarvik, 1980 and citations therein), is found at Miguasha, nevertheless Jarvik had never previously visited the locality (in Jarvik's publications this locality is cited as Escuminac or Scaumenac Bay). Eusthenopteron is often taken as an example of a fish on the transition to tetrapods, although Elpistostege, also from Miguasha, is closer to the tetrapods. Thus in addition to talks about the fauna and flora of Miguasha (see Schultze \& Cloutier, 1996), the transition to tetrapods (Clack \& Coates, 1995; Coates \& Clack, 1995; Carroll, 1995) was an important theme of the symposium. Nevertheless, most participants (Figure 12) chose to present descriptions of new forms and their relationships. The first meeting of the IGCP 328 research group on the biostratigraphy of microvertebrates, initiated by S. Turner and G. C. Young, also took place during the symposium in Miguasha. The results of the seventh symposium (Arsenault et al. 1995) and those of the eighth (Lelièvre et al., 1995) were published in the same year.

The field trips visited the Devonian of Gaspé Peninsula and the Carboniferous of Nova Scotia.

8. Premiers Vertébrés et Vertébrés Inférieurs. Paris, France, Septembre 4-9, 1995 with 103 participants: 21 France, 11 Great 

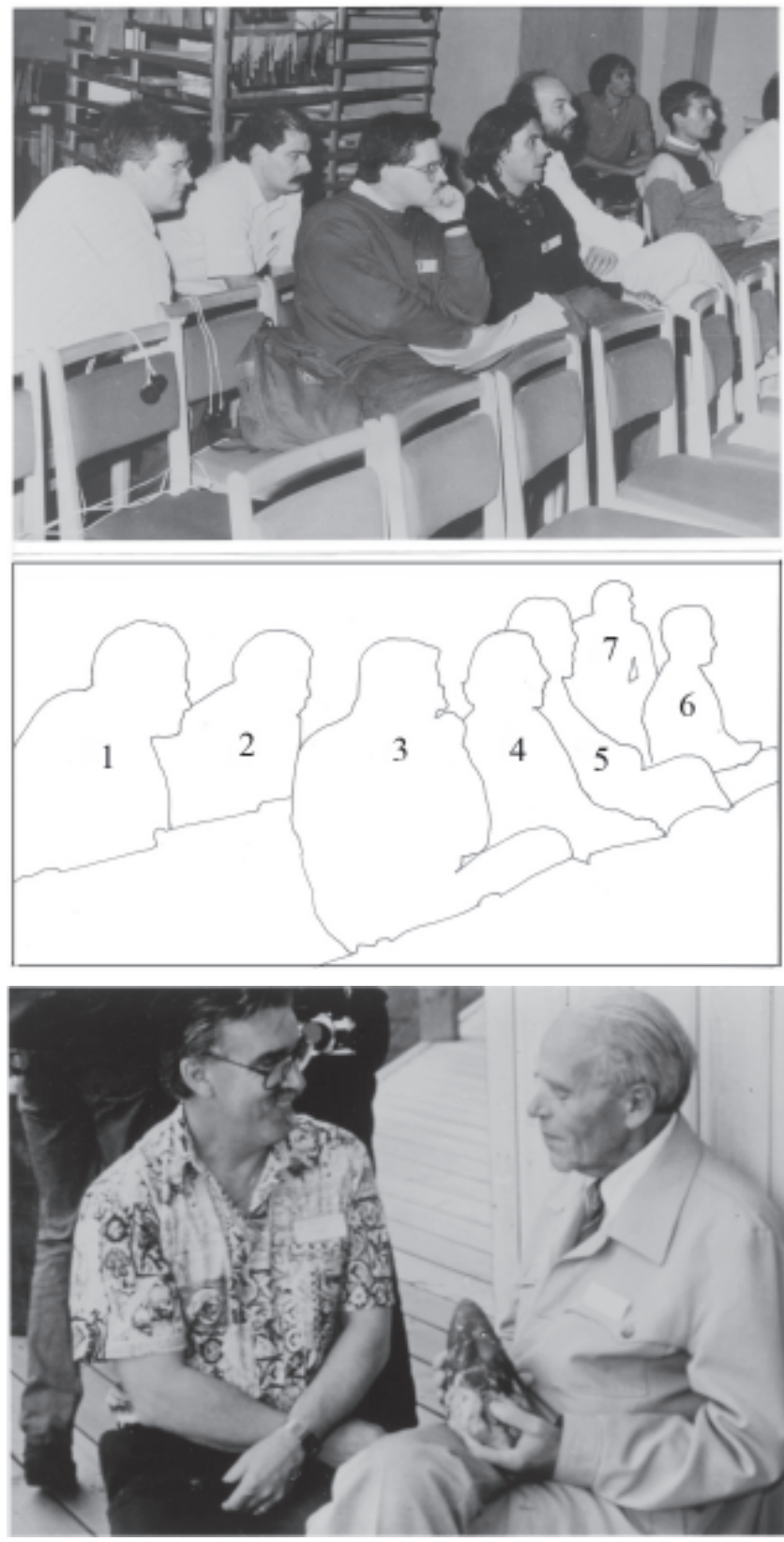

Figure 11. E. Jarvik, Stockholm, with M. Arsenault, Miguasha, at the seventh symposium in Miguasha 1991.
Figure 10. The young guard during a lecture at the sixth symposium in Tallinn 1989: 1. M. J. Belles-Isles; 2. D. Vézina; 3. M. D. Gottfried; 4. H. Lelièvre; 5. P.-Y. Gagnier; 6. M. Ginter; 7. M. Otto, (photo by Erik Grünberg, Tallinn).

Britain, 9 Russia, 9 USA, 8 Australia, 7 Canada, 6 China, 5 Germany, 4 Lithuania, 3 Netherlands, 3 Saudi Arabia, 2 Latvia, 2 Estonia, 2 Italy, 2 Czechian, 2 Spain, 1 Belgium, 1 Ireland, 1 Poland, 1 Sweden, 1 Slovakia, 1 Belarus, 1 Brasil (70 presentations +22 poster). Field trip: Devonian and Carboniferous of northern France and Belgium. Proceedings: Lelièvre, H., Wenz, S., Blieck, A. \& Cloutier, R. (eds) 1995 (69 papers).

In 1995, the eighth symposium, "Premiers Vertébrés et Vertébrés Inférieurs," was held in Paris. This was the largest symposium held so far with over 100 participants (Figure 13) from 23 different countries. Seventy three talks and 23 posters were presented. The presentations were systematically arranged, running from "agnathans" to sarcopterygians, and divided into nearly equal sessions on histology/"agnathans," placoderms, chondrichthyans + acanthodians, actinopterygians and sarcopterygians. There were more talks on histology than usually occur at the symposia, two dealing with Harding Sandstone remains. Twenty two percent of the talks were presented in the sessions dedicated to microvertebrate biochronology (IGCP 328), the final meeting of research group IGCP 328 (Blieck \& Turner, 2000).

An field trip to the Devonian and Carboniferous of northern France and Belgium followed the symposium, which ended in a visit of a champagne cave.

\section{9. $9^{\text {th }}$ International Symposium Early Vertebrates/Lower} Vertebrates. Flagstaff, Arizona, USA, May 15-19, 2000 with 82 participants: 37 USA, 10 Great Britain, 8 Australia, 6 Canada, 5 France, 4 Germany, 2 Russia, 2 Estonia, 1 South Africa, 1 Sweden, 1 Ireland, 1 Poland, 1 Latvia, 1 Italy, 1 Netherlands, 1 China (44 presentations +9 poster). Field trip: Devonian of Nevada and Utah, Dinosaur National Monument, Colorado, Eocene (Green River) of Wyoming and Colorado. Proceedings: Elliott, D. K. \& Gottfried, M. D. (eds.) 2001 (20 papers).

In 2000, the ninth symposium was held in Flagstaff, Arizona, and, again, was very well attended with many North American colleagues taking part. English colleagues tried to convince the palaeoichthyologists that carpoids (R. P. S. Jefferies: calcichordate theory) and conodonts (P. C. J. Donoghue) are chordates and vertebrates respectively. The papers on fishes were nearly equally distributed among "agnathans", placoderms, chondrichthyans and osteichthyans. In addition there were six papers on early tetrapods. A meeting of IGCP 406 also took place.

Only a few of the numerous talks and posters given at the meeting were published in a special issue of the Journal of Vertebrate Paleontology (Elliott \& Gottfried, 2001), but nevertheless the issue contained some very important contributions. Braincases, with fissures, of an Early Devonian and a Late Devonian chondrichthyan were described (Maisey \& Anderson, 2001; Maisey, 2001a) supporting an earlier proposal by Maisey (2001b) that the occurrence of fissures is a primitive gnathostome feature, in common to chondrichthyans and teleostomes. The detailed description of an Early Devonian actinopterygian braincase (Basden \& Young, 2001) demonstrated another common feature of gnathostomes: the occurrence of an eyestalk, as in placoderms (Goujet, 1984b), elasmobranchs (Gross, 1937) and sarcopterygians (Zhu et al., 2001). Sahney \& Wilson (2001) (Figure 14) argued that an open endolymphatic duct allowing the entrance of extrinsic grains into the labyrinth, is primitive for osteostracans and gnathostomes because grain-filled labyrinths occur in Early Devonian osteostracans, acanthodians and putative chondrichthyans. 
The field trip following the symposium visited Devonian localities in Nevada and Utah (Figure 15) and Paleogene (Green River Formation) localities in Wyoming and Colorado.

10. 10 ${ }^{\text {th }}$ International Symposium on Early Vertebrates/Lower Vertebrates. Gramado, State of Rio Grande do Sul, Brazil, May 24-28, 2004 with 34 participants: 7 USA, 5 Brazil, 5 France, 3 Canada, 2 China, 2 Germany, 2 Great Britain, 2 Spain, 1 Autsralia, 1 Czech Republic, 1 Estonia, 1 Russia, 1 Sweden, 1 South Africa, 1 Uruguay (35 presentations + 12 poster). Field trip: Upper Palaeozoic/Mesozoic rocks of the Paraná Basin in the States of Rio Grande do Sul and Santa Catarina, southern Brasil. Proceedings: 8 papers in this volume.
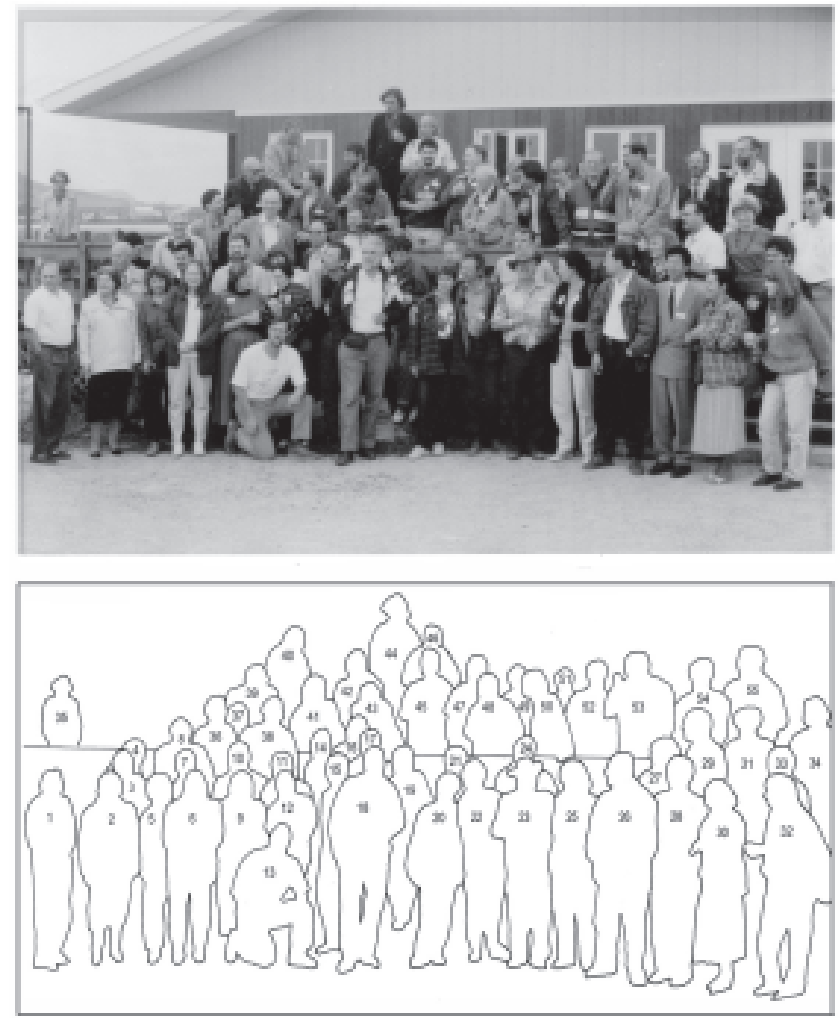

Figure 12. Participants of the seventh symposium in 1991 after the lobster meal at Pointe Tracadigash: 1. C. Lavallée; 2. L. Novitskaya; 3. E. Jarvik; 4. A. Ivanov; 5. V. T. Young; 6. K. DennisBryan; 7. A. Tintori; 8. R. E. Barwick; 9. E. I. Vorobyeva; 10. J. McAllister; 11. M. Johns; 12. S. Turner; 13. A. Ritchie; 14. Wang Nian-zhong; 15. J. M. J. Vergoosen; 16. Mr. Clack; 17. N. Krupina; 18. J. Bolt; 19. J. A. Clack; 20. Wendy Lund; 21. R. L. Carroll; 22. R. Lund; 23. M. Arsenault; 24. R. K. Carr; 25. C. Poplin; 26. O. Hampe, V. Karatajuté-Talimaa (behind Hampe); 27. T. Märss; 28. Wang Ronghu; 29. N. Parent; 30. G. Arratia; 31. S. M. Andrews; 32. C. Derycke; 33. O. Lebedev; 34. E. Albert; 35. Mrs Frickhinger; 36. R. Cloutier; 37. Chang Mee-mann; 38. R. P. S. Jefferies; 39. H. C. Bjerring; 40. H.-P. Schultze; 41. D. Goujet; 42. A. Blieck; 43. M. I. Coates; 44. H. Lelièvre; 45. J. Hitchkock; 46. P. Lemieux; 47. J. Chorn; 48. Y. Pageau; 49. K. S. W. Campbell; 50. P. Janvier; 51. P. Gensel; 52. Mr. Gensel; 53. D. Vézina; 54. P. L. Forey; 55. M. V. H. Wilson. (Young \& Moody, 2002). The organising committee, headed by Martha Richter, had invited speakers to give overviews on selected subjects. These talks on the history of the symposia, the position of vertebrates within deuterostomes, the phylogenetic origin of teeth, the transition from piscine sarcopterygians to tetrapods and the relation between ontogeny and phylogeny in teleosts, introduced very welcomed elaborations on the subjects. Most papers arranged from "agnathans" to tetrapods, described new forms and characters, few presented phylogenetic analyses. A functional analysis of a pteraspid model faulted earlier ideas on the swimming of pteraspids. A meeting of IGCP 491 was held.

Brazilian Permocarboniferous localities (similar to localities in Uruguay) were visited following the symposium in Gramado.

The presentation above corresponds to the sequence of "official" symposia. In addition, there were other meetings, that were attended by groups of palaeoichthyologists between the listed symposia. At the beginning, the CNRS meetings on "Évolution des Vertébrés" organized by J.-P. Lehman in Paris in 1966 and in 1973 (see Lehman, 1967, 1975) competed with the symposia on fossil fishes. By contrast to the Paris meetings in 1966 and 1973, the first two symposia on early vertebrates in 1967 and in 1972 were more focused and lay more in the main stream of the evolution of phylogenetic approaches.

The creation of an active group using microvertebrates for biostratigraphy required annual meetings or workshops, that in most cases were held in connection with other meetings. After the start of the correlation program UNESCO-IUGS IGCP 328 ("Palaeozoic Microvertebrates") 1991-1993 under the guidance of S. Turner and G. C. Young and 1993-1996 under the guidance of A. Blieck and S. Turner at the seventh symposium in Miguasha in 1991, a sequence of meetings followed between 1991 and 1995. These were as follows: in 1992 in Guilin ("International Symposium on the Devonian System and its Economic Oil and Mineral Resources") and in Beijing, China; in 1993 in Göttingen, Germany (Gross Symposium: Turner \& Blieck, 1996, 1997); in 1994 in Moscow, Russia (Turner, 1995); and the final meeting in 1995 at the eighth symposium in Paris (Blieck \& Turner, 2000). IGCP 328 was followed by IGCP 406 ("Circum Arctic Palaeozoic Vertebrates" under the guidance of M. V. H. Wilson and T. Märss) with workshops in 1996 in Uppsala, Sweden, in Edmonton, Canada, and in Tallinn, Estonia (3rd Baltic Stratigraphy meeting), in 1997 in Buckow, Germany (Wilson, 1997), and in St. Petersburg, Russia (Ivanov et al., 1997), in 1998 in Warsaw, 


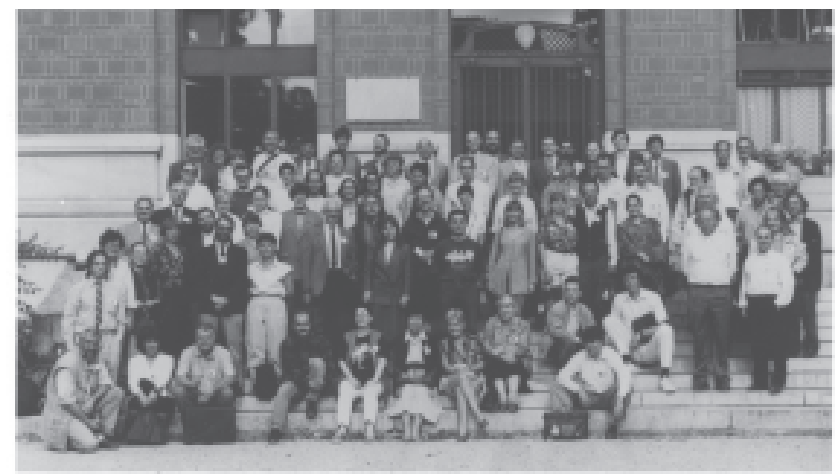

Figure 13. Participants of the eighth symposium in Paris in 1995: 1. J. Schneider; 2. V. T. Young; 3. R. K. Carr; 4. M. Ginter; 5. S. Turner; 6. Chang Mee-mann; 7. M. M. Smith; 8. V. KaratajutéTalimaa; 9. N. Panteleev; 10. D. Esin; 11. A. A. Tessarsky; 12. J. Zajic; 13. R. Soler-Gijón; 14. G. V. Zakharenko; 15. R. Mertiniene; 16. G. C. Young; 17. N. Krupina; 18. D. L. Dineley; 19. I. Upeniece; 20. A. de la Peña Zarzuelo; 21. M. Richter; 22. Wendy Lund; 23. R. Lund; 24. G. Arratia; 25. H.-P. Schultze; 26. D. Goujet; 27. S. Kruchek; 28. J. Valiukevicius; 29. M. Duncan; 30. E. Luksevics; 31. C. Burrow; 32. J. Klembara; 33, 34, 35. C. Lombardo; 36. K. Trinajstic; 37. W. Kathe; 38. C. Poplin; 39. J. A. Long; 40. M. Arsenault; 41. M. Martin; 42. M. Véran; 43. O. Otero; 44. D. K. Elliott; 45. N. M. Pellerin; 46.M. Otto; 47. T. Märss; 48. H. Blom; 49. J. M. J. Vergoossen; 50. A. Bannikov; 51. M. A. Murphy; 52. P. Carls; 53. P. Janvier; 54. K. Dennis-Bryan; 55. S. Wenz; 56. H. Lelièvre; 57. Mr. A. and 58. Mrs. Hoverstadt; 59. C. Derycke; 60. M. V. H. Wilson; 61. A. Tintori; 62. P. H. Lambers; 63. A. Blieck; 64. L. Sorbini; 65. A. de Ricqlès; 66. P.-Y. Gagnier; 67. S. Stamberg; 68. O. Hampe; 69. O. Lebedev; 70. E. Mark-Kurik; 71. A. Ivanov; 72. Zhu Min; 73. Wang Shi-tao; 74. P. L. Forey; 75. P. Taquet (photo by Denis Serrette, Muséum national d'Histoire naturelle, Paris).

Poland (Ginter \& Wilson, 1998), in 1999 in Jurmala, Latvia (Luksevics et al., 1999), in 2000 in Flagstaff, Arizona, USA, at the ninth symposium, and with a final meeting in 2000 in

Syktyvkar, Russia (Antoshkina et al., 2000). The correlation programms have been continued with IGCP 491 ("Middle Palaeozoic Vertebrate Biogeography, Palaeogeography, and Climate" under the guidance of Zhu Min and G. C. Young) which started in 2003 at the 2nd Gross Symposium in Riga, Latvia (Schultze et al., 2003).

In 1993, the 90th birthday of Walter Gross was commemorated with a symposium in Göttingen, Germany (Turner \& Blieck, 1996, 1997), attended by 58 palaeoichthyologists. In 1999, P. Ahlberg organized a special symposium "Major Events in Early Vertebrate Evolution" in London, England, to enhance the cooperation, or at least the contact, between vertebrate palaeontologists and molecular and developmental biologists (Ahlberg, 2001). A small group of palaeoichthyologists, mainly pupils of D. V. Obruchev and their students, met in 2000 in Moscow, one year after Obruchev's 100th birthday. In 2003, the 100th birthday of W. Gross was celebrated in Riga with the participitation of 50 palaeoichthyologists (Schultze et al., 2003).

\section{STATISTICS OF THE SYMPOSIA}

The symposia on early vertebrates were always small events with less than one hundred participants (exception Paris 1995: 103). The first five symposia had less than 60 participants. The hosting country is always represented by the highest number of participants. The centers of palaeoichthyology have moved from country to country over the years. The 1960's were the high point in Stockholm. Thereafter, the number of palaeoichthyologists in Sweden has dropped, until they have nearly disappeared; four were present at the second, three at the third, and two at the seventh symposium. The center of research in palaeoichthyology had moved to Great Britain and France by the end of the 1960's. The French group had been build by J.-P. Lehman, a pupil of E. Stensiö, in the 1960's, whereas palaeoichthyology had a long tradition in Great Britain. At present the pupils of J.-P. Lehman are reaching retirement age, and few young palaeoichthyologists have taken their places so that the group of French palaeoichthyologists is thinning out. A similar situation is happening in Great Britain. The group of Soviet palaeoichthyologists formed by D. V. Obruchev in the 1950's and 1960's, was somewhat isolated by the political situation; only D. V. Obruchev and E. I. Vorobyeva took part in the first symposium in Stockholm. D. V. Obruchev, who had students from Russia, the Baltic region and even China, was as of great importance for palaeoichthyology in the East as E. Stensiö was in the West. There is still a large group of young palaeoichthyologists in Russia and the Baltic States.

The symposia in Australia and China introduced new active centers with young palaeoichthyologists and important new finds of Palaeozoic fishes. The Australian palaeoichthyologists are still very active, even though many are retired. In China, the situation for palaeoichthyology has improved, and the group is still very active and diversifying.

The number of contributions in the proceedings, when compared to papers given at symposia decreased from $72 \%$ and $93 \%$ in the first two symposia to $39 \%$ in the seventh and $23 \%$ in the ninth (Table 1). The eighth symposium is an exception where this value reached $73 \%$, because extended abstracts were requested before the symposium. This reflects a situation wherein authors preferred to submit (or had already submitted) their manuscripts to another journal or book as, for example, was the case with the contributions on Miguasha fossils at the seventh symposium, subsequently published as a book (Schultze \& Cloutier, 1996). At the fourth symposium, many participants gave more than one presentation. The editors of the proceedings 

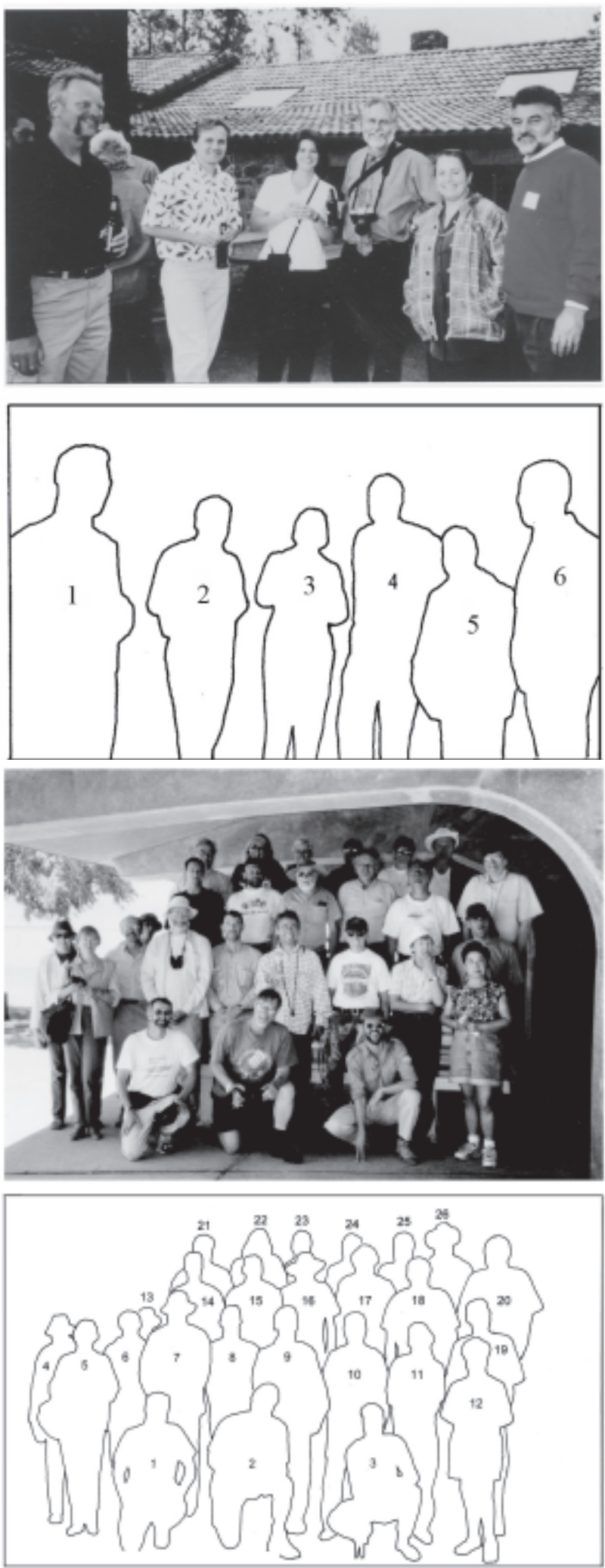

Figure 15. Participants of the field trip of the ninth symposium on the salt flats east of Wendover, Nevada, 2000: 1. G. C. Young; 2. A. Ritchie; 3. A. Blieck; 4. E. Mark-Kurik; 5. O. B. Afanassieva; 6. D. K. Elliott; 7. M. V. H. Wilson; 8. Mr. Burrow; 9. J. M. J.Vergoosen; 10. B. Albright; 11. T. Märss; 12. Chang Ying-chien; 13. M. Duncan; 14 J. A. Long; 15. E. Luksevics; 16. G. Johnson; 17. H.-P. Schultze; 18. M. Arsenault; 19. M. Otto; 20. A. Ivanov; 21. D. Goujet; 22. K. DennisBryan; 23. C. Burrow; 24. D. Gillette; 25. E. Grogan; 26. R. Lund.
Figure 14. Canadian palaeoichthyologists in the Museum of Northern Arizona before the banquet of the ninth symposium in 2000: 1. A. Lindoe; 2. G. Hanke; 3. B. Hunda; 4. M. V. H. Wilson; 5. G. Arratia; 6. A. Tintori.

accepted a few contributions that were not presented at the symposia because participants were requested to offer a "more" interesting subject. Contributions in honour of E. Stensiö were solicited for the proceedings of the first symposium. The ten additional contributions in the proceedings (extended abstracts) of the eighth symposium represent abstracts of presentations that were not given at the symposium.

Personal attendance of the symposia has fluctuated considerably. Only a few people have attended most of the symposia. The author participated in all, whereas D. Goujet only missed the second symposium in London. A. Blieck and S. Turner, the organizers of IGCP 328, were present at seven symposia, and M. M. Smith and E. I. Vorobyeva at six. At the first two symposia the old guard with A. Heintz, E. Jarvik, J.-P. Lehman, O. Nybelin, F. R. Parrington, B. Schaeffer, T. S. Westoll, E. I. White and R. Zangerl were present (S. M. Andrews, S. E. BendixAlmgren, H. C. Bjerring, N. Bonde, R. S. Miles, G. J. Nelson, C. Patterson, and H.-P. Schultze also attended). At the second symposium some of the old palaeoichthyologists such as W. Gross, R. H. Denison, D. V. Obruchev, T. Ørvig and E. Stensiö were already missing. T. S. Westoll and J.-P. Lehman attended the third, and E. Jarvik the third and seventh symposium.

\section{CONCLUDING REMARKS}

The first symposium on early vertebrates marked the end of the "classic era" of palaeoichthyology and the start of a new approach to phylogenetic systematics. Many controversies discussed in the first symposium were later decided following the introduction of new ideas. The diphyly of cyclostomes (Stensiö, 1968) changed to the question of the placement of the petromyzontoids between Palaeozoic "agnathans", with anaspids (Janvier, 1981) or below all armoured "agnathans" (Janvier, 1996), whereas the myxinoids moved to the base of the Craniata. A group "Cyclostomata," as found in many zoology textbooks, is no longer accepted.

Most changes in phylogenetic relationships concern the gnathostomes. Placoderms are no longer placed as a sister group of chondrichthyans; and two researchers, Goujet \& Young (e.g. 1995), have changed the way we see the interrelationships of the groups within placoderms. The acanthodians are today considered as a sister group to the osteichthyans (Miles, 1968, 1973) in contrast to earlier ideas which placed them closer to chondrichthyans, or even placoderms. Nevertheless, some characters that are used to place acanthodians and osteichthyans together as Teleostomi, also occur in chondrichthyans (Maisey, 2001a, b). Even a feature like the eyestalk, once considered a unique feature of chondrichthyans, occurs in placoderms (Goujet, 1984b), actinopterygians (Basden \& Young, 2001) and sarcopterygians (Zhu et al., 2001). The division of osteichthyans 
Table 1. Number of participants, presentations and posters at the symposia, and papers published in the proceedings.

\begin{tabular}{|c|c|c|c|c|}
\hline 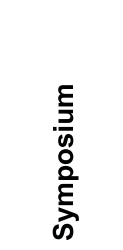 & 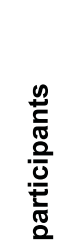 & 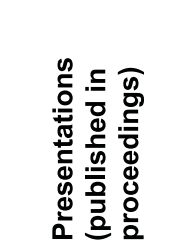 & 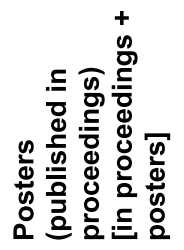 & 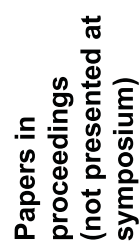 \\
\hline 1.1967 & 47 & $18(13=72 \%)$ & 0 & $28(15)$ \\
\hline 2. 1972 & $23+$ & $14(13=93 \%)$ & 0 & $15(1)$ \\
\hline 3. 1976 & 35 & 26 & 0 & 0 \\
\hline 4. 1983 & 22 & $28(13=46 \%)$ & 0 & $14(1)$ \\
\hline 5. 1987 & 42 & $34(21=62 \%)$ & 0 & $21(0)$ \\
\hline 6. 1989 & 62 & $32(21=66 \%)$ & $13(5)$ [58\%] & $29(3)$ \\
\hline 7. 1991 & 58 & $41(16=39 \%)$ & 0 & $20(4)$ \\
\hline 8. 1995 & 103 & $70(51=73 \%)$ & 22 (8) [64\%] & $69(10)$ \\
\hline 9. 2000 & 82 & $44(13=30 \%)$ & $9(1)$ [26\%] & $20(6)$ \\
\hline 10.2004 & 34 & $35(12=34 \%)$ & 12 & $9(0)$ \\
\hline
\end{tabular}

into Actinopterygii and Sarcopterygii is accepted. Different schemes of the interrelationships of the various groups within higher taxa of sarcopterygians still exist. Nevertheless, it is generally accepted that the tetrapods are monophyletic and their closest relatives are the Elpistostegalia and "Osteolepiformes." The second symposium already took place completely in the spirit of Hennig's phylogenetic principles and was marked by the absence of some of the old guard. Many phylogenetic results of the contributions in the proceedings of the second symposium are still accepted and treated as classic papers (e.g. Patterson, 1973). The approach of basing interrelationships on similarities, has been replaced by a search of shared derived features (synapomorphies) indicating sister group relationships.

The most important role of the symposia was to enhance cooperation between palaeoichthyologists of different countries, especially in the area of microvertebrate biostratigraphy. Even support could be raised from UNESCO for this project. Moreover, the symposium in Miguasha gave the director the leverage to enlarge the facilities at the park. Thus the symposia provided the possibility for raising support in addition to promoting scientific cooperation.

\section{ACKNOWLEDGMENTS}

The author thanks D. Goujet (Paris) and G. Arratia (Berlin) for reading and commenting on the manuscript. D. Goujet, and A. Ritchie, Sydney, kindly supplied pictures of the first and third symposia; M. Arsenault (Miguasha) for the seventh symposium. K. Dennis-Bryan discovered the hidden list of participants of the second symposium, therefore a special thank to her. C. Radke and E. Siebert, Berlin, prepared the published prints from slides and color pictures. D. Unwin is given special thanks for correcting the English. The author thanks for the suggestions of two reviewers, A. Blick and D.K. Elliott.

\section{REFERENCES}

Agassiz, L. 1833-1844. Recherches sur les Poissons fossiles. Neuchâtel et Soleure, Petitpierre, Tomes I-V.

Ahlberg, P.E. (ed.) 2001. Major Events in Early Vertebrate Evolution. Palaeontology, phylogeny, genetics and development. London and New York, Taylor \& Francis, 418 p.

Andrews, S.M. 1973. Interrelationships of crossopterygians. In: P.H.Greenwood; R.S. Miles \& C. Patterson (eds.) Interrelationships of Fishes. Academic Press, p. 137-177.

Antoshkina, A.; Malysheva, E. \& Wilson, M.V.H. (eds.) 2000. Pan-Arctic Palaeozoic Tectonics, Evolution of Basins and Faunas. Ichthyolith Issues, Special Publication, 6:1-166.

Arratia, G. 1991. The caudal skeleton of Jurassic teleosts; a phylogenetic analysis. In: Chang Mee-mann, Liu Yu-hai \& Zhang Guo-rui (eds) Early Vertebrates and Related Problems of Evolutionary Biology. Science Press, p. 249-340.

Arratia, G. \& Cione, A. 1996. The record of fossil fishes of southern South America. In: G. Arratia, (ed.) The Contribution of Southern South America to Vertebrate Paleontology. Münchner Geowissenschaftliche Abhandlungen, Reihe A: Geologie und Paläontologie 30:9-72.

Arsenault, M.; Lelièvre, H. \& Janvier, P. (eds.) 1995. Études sur les Vertébrés inférieurs. Muséum national d'Histoire naturelle, Paris, 529 p.

Basden, A.M. \& Young, G.C. 2001. A primitive actinopterygian neurocranium from the Early Devonian of southeastern Australia. Journal of Vertebrate Paleontology, 21(4):754-766.

Bendix-Almgren, S. E. 1968. The bradyodont elasmobranchs and their affinities; a discussion. In: T.Ørvig (ed.) Current Problems of Lower Vertebrate Phylogeny. Almqvist \& Wiksells, p. 153-170.

Bertmar, G. 1968. Lungfish phylogeny. In: T. Ørvig (ed.) Current Problems of Lower Vertebrate Phylogeny. Almqvist \& Wiksells, p. 259283.

Bjerring, H.C. 1973. Relationships of coelacanthiforms. In: P.H. Greenwood; R.S. Miles, \& C.Patterson (eds.) Interrelationships of Fishes. Academic Press, p. 179-205.

Blieck, A. \& Turner, S. (eds.) 2000. Palaeozoic Vertebrate Biochronology and Global Marine/Non-Marine Correlation. Final Report of IGCP 328 (1991-1996). Courier Forschungsinstitut Senckenberg. (223):1-575.

Brundin, L. 1968. Application of phylogenetic principles in systematics and evolutionary theory. In: Ørvig, T. (ed.) Current Problems of Lower Vertebrate Phylogeny. Uppsala, Almqvist \& Wiksells, p. 473-495.

Campbell, K.S.W. \& Barwick, R.E. 1984. The choana, maxillae, premaxillae and anterior palatal bones of early dipnoans. Proceedings of the Linnean Society of New South Wales, 107(3):147-170. 
Campbell, K.S.W. \& Barwick, R.E. 1991. Teeth and tooth plates in primitive lungfish and a new species of Holodipterus. In: Chang Meemann; Liu Yu-hai \& Zhang Guo-rui (eds.) Early Vertebrates and Related Problems of Evolutionary Biology, Science Press, p. $429-440$.

Campbell, K.S.W.; Ritchie, A.; Warren, J.W. \& Young, G.C. (eds.) 1984. Evolution \& Biogeography of Early Vertebrates. Proceedings of the Linnean Society of New South Wales, 107(3):147-473.

Carroll, R. L. 1995. Problems of the phylogenetic analysis of paleozoic choanates. In: Arsenault, M.; Lelièvre, H. \& Janvier, P. (ed.) Études sur les Vertébrés inférieurs. Muséum national d'Histoire naturelle, Paris, p. 389-445.

Chang Mee-mann; Liu Yu-hai \& Zhang Guo-rui (eds.) 1991. Early Vertebrates and Related Problems of Evolutionary Biology. Beijing, Science Press, 514 p.

Chang Mee-mann \& Yu Xiaobo 1984. Structure and phylogenetic significance of Diabolichthys speratus gen. et sp. nov., a new dipnoan-like form from the Lower Devonian of eastern Yunnan, China. Proceedings of the Linnean Society of New South Wales 107(3):171-184.

Clack, J.A. \& Coates, M.I. 1995. Acanthostega gunnari, a primitive, aquatic tetrapod? In: Arsenault, M.; Lelièvre, H. \& Janvier, P. (eds) Études sur les Vertébrés inférieurs. Muséum national d'Histoire naturelle, Paris, p. 359-372.

Coates, M.I. \& Clack, J.A. 1995. Romer's gap: tetrapod origins and terrestriality. In: Arsenault, M.; Lelièvre, H. \& Janvier, P. (eds) Études sur les Vertébrés inférieurs. Muséum national d'Histoire naturelle, Paris, p. 373-388.

Compagno, L.J.V. 1973. Interrelationships of living elasmobranchs. In: P.H. Greenwood; R.S. Miles, \& C.Patterson (eds.) Interrelationships of Fishes. Academic Press, p.15-61.

Denison, R.H. 1968. The evolutionary significance of the earliest known lungfish, Uranolophus. In: Ørvig, T. (ed.) Current Problems of Lower Vertebrate Phylogeny. Almqvist \& Wiksells, p. 247-257.

Elliott, D.K. \& Gottfried, M.D. (eds.) 2001. 9th International Meeting on Early Vertebrates/Lower Vertebrates. Journal of Vertebrate Paleontology, 21(4):637-820.

Gagnier, P.-Y. 1992. Ordovician vertebrates from Bolivia: Comments on Sacabambaspis janvieri and Andinaspis suarezorum. Revista Técnica de Yacimientos Petrolíferos Fiscales Bolivianos, 12(3-4):371-379.

Gardiner, B.G. 1973. Interrelationships of teleostomes. In: P.H. Greenwood; R.S. Miles, \& C. Patterson (eds.) Interrelationships of Fishes. Academic Press, p.105-135.

Ginter, M. \& Wilson, M.V.H. (eds.) 1998. Circum-Arctic Palaeozoic Faunas and Facies. Ichthyolith Issues Special Publication, 4:1-62.

Goujet, D.F. 1984a. Placoderm interrelationships: a new interpretation, with a short review of placoderm classifications. Proceedings of the Linnean Society of New South Wales, 107(3):211-243.

Goujet, D. 1984b. Les poissons placodermes du Spitsberg. Arthrodires Dolichothoraci de la Formation de Wood Bay (Dévonien inférieur). Cahiers de paléontologie. Paris, Centre National de la Recherche Scientifique, p. 1-284.

Goujet, D. 2001. Placoderms and basal gnathostome apomorphies. In: Ahlberg, P. E. (ed.) Major Events in Early Vertebrate Evolution. Palaeontology, phylogeny, genetics and development. Taylor \& Francis, p. 209-222.

Goujet, D. \& Young, G. C. 1995. Interrelationships of placoderms revisited. In: Lelièvre, H.; Wenz, S.; Blieck, A. \& Cloutier, R. (eds.) Premiers vertébrés et vertébrés inférieurs. Geobios, Mémoire spécial, 19:89-95.

Greenwood, P.H. 1973. Interrelationships of osteoglossomorphs. In: P.H. Greenwood; R.S. Miles, \& C. Patterson (eds.) Interrelationships of Fishes. Academic Press, p. 307-332.

Greenwood, P.H.; Miles, R.S. \& Patterson, C. (eds.) 1973. Interrelationships of Fishes. Academic Press, 536 p.

Gross, W. 1937. Das Kopfskelett von Cladodus wildungensis JAEKEL. 1. Teil. Endocranium und Palatoquadratum. Senckenbergiana, 19:80-107.

Hennig, W. 1950. Grundzüge einer Theorie der phylogenetischen Systematik. Berlin, Deutscher Zentralverlag, 370 p.

Hennig, W. 1966. Phylogenetic systematics. Urbana, University of Illinois Press, 263 p.

Ivanov, A., Wilson, M.V.H. \& Zhuravlev, A. (eds.) 1997. Palaeozoic Strata and Fossils of the Eurasian Arctic. Ichthyolith Issues. Special Publication, 3:1-60.

Janvier, P. 1981. The phylogeny of the Craniata, with particular reference to the significance of fossil "agnathans". Journal of Vertebrate Paleontology, 1(2):121-159.

Janvier, P. 1992. The Silurian and Devonian vertebrates of Bolivia. In: Suárez-Soruco, R. (ed.) Fósiles y Facies de Bolivia . Volumen I. Vertebrados. Revista Técnica de Yacimiento Petrolíferos Fiscales Bolivianos, 12(3-4):381-388.

Janvier, P. 1996. Early Vertebrates. Oxford Monographs on Geology and Geophysics 33. Oxford, Clarendon Press, XIII + 393 p.

Janvier, P. \& Melo, J.H.G. 1988. Acanthodian fish remains from the Upper Silurian or Lower Devonian of the Amazon Basin, Brazil. Palaeontology, 31:771-777.

Jarvik, E. 1967. The homologies of frontal and parietal bones in fishes and tetrapods. In: COLLOQUES INTERNATIONAUX DU CENTRE NATIONAL DE LA RECHERCHE SCIENTIFIC, 163: Problèmes actuels de Paléontologie (Évolution des Vertébrés), p. 181-213.

Jarvik, E. 1968a. The systematic position of the Dipnoi. In: Ørvig, T. (ed.) Current Problems of Lower Vertebrate Phylogeny. Almqvist \& Wiksells, p. 223-245.

Jarvik, E. 1968b. Aspects of vertebrate phylogeny. In: Ørvig, T. (ed.) Current Problems of Lower Vertebrate Phylogeny. Uppsala, Almqvist \& Wiksells, p. 497-527.

Jarvik, E. 1977. The systematic position of acanthodian fishes. In: Andrews, S. M., Miles, R. S., \& Walker, A. D. (eds) Problems in Vertebrate Evolution. Academic Press, p. 199-225.

Jarvik, E. 1980. Basic Structure and Evolution of Vertebrates. London, Academic Press, Volume 1, 575 p.

Jessen, H.L. 1973. Interrelationships of actinopterygians and brachiopterygians: evidence from pectoral anatomy. In: P.H. Greenwood; R.S. Miles, \& C. Patterson (eds.) Interrelationships of Fishes. Academic Press, p. 227-232.

Jollie, M. 1962. Chordate Morphology. New York, Reinhold Publishing Corporation, XIV + 478 p. 
Kurss, V. 1992. Depositional environment and burial conditions of fish remains in Baltic Middle Devonian. In: Mark-Kurik, E. (ed.) Fossil fishes as living animals. Tallinn, Academy of Sciences of Estonia, Academia 1:251-260.

Lehman, J.-P. (organizer) 1967. Problèmes actuels de Paléontologie. Évolution des Vertébrés. Colloques Internationaux du Centre National de la Recherche Scientifique No. 163: p. 662. Paris, CNRS.

Lehman, J.-P. 1968. Remarques concernant la phylogénie des Amphibiens. In: T. Ørvig (ed.) Current Problems of Lower Vertebrate Phylogeny. Almqvist \& Wiksells, p. 307-315.

Lehman, J.-P. (organizer) 1975. Problèmes actuels de Paléontologie. Évolution des Vertébrés. Colloques Internationaux du Centre National de la Recherche Scientifique, 218:911.

Lelièvre, H.; Janvier, P. \& Blieck, A. 1993. Silurian-Devonian vertebrate biostratigraphy of Western Gondwana and related terranes (South America, Africa, Armorica-Bohemia, Middle East). In: J. A. Long (ed.) Palaeozoic Vertebrate Biostratigraphy and Biogeography. London, Belhaven Press, p. 139-173.

Lelièvre, H.; Wenz, S.; Blieck, A. \& Cloutier, R. (eds) 1995. Premiers Vertébrés et Vertébrés inférieurs. Geobios, Mémoire spécial, 19:1-409.

Luksevics, E., Stinkulis, G. \& Wilson, M. V. H. 1999. Lower-Middle Palaeozoic Events across the Circum-Arctic. Ichthyolith Issues Special Publication 5:1-67.

Maisey, J. G. 2001a. CT-scan reveals new cranial features in Devonian chondrichthyan "Cladodus" wildungensis. Journal of Vertebrate Paleontology 21 (4):807-810.

Maisey, J.G. 2001b. A primitive chondrichthyan braincase from the Middle Devonian of Bolivia. In: Ahlberg, P. E. (ed.) Major Events in Early Vertebrate Evolution. Palaeontology, phylogeny, genetics and development. Systematics Association Special Volume Series 61: 263-288.

Maisey, J.G. \& Anderson, M. E. 2001. A primitive chondrichthyan braincase from the Early Devonian of South Africa. Journal of Vertebrate Paleontology 21(4):702-713.

Mark-Kurik, E. (ed.) 1992. Fossil fishes as living animals. Tallinn, Academy of Sciences of Estonia, 299 p.

Miles, R.S. 1968. Jaw articulation and suspension in Acanthodes and their significance. In: T. Ørvig (ed.) Current Problems of Lower Vertebrate Phylogeny. Almqvist \& Wiksells, p. 109-127.

Miles, R.S. 1973. Relationships of acanthodians. In: P.H. Greenwood; R.S. Miles, \& C. Patterson (eds.) Interrelationships of Fishes. Academic Press, p. 63-103.

Nelson, G.J. 1968. Gill-arch structure in Acanthodes. In: Ørvig, T. (ed.) Current Problems of Lower Vertebrate Phylogeny. Uppsala, Almqvist \& Wiksells, p. 129-143.

Ørvig, T. 1966. Histologic studies of Ostracoderms, Placoderms and fossil Elasmobranchs. 2. On the dermal skeleton of two Palaeozoic Elasmobranchs. Arkiv för Zoologi, 19(1):1-39.

Ørvig, T. (ed.) 1968. Current Problems of Lower Vertebrate Phylogeny. Uppsala, Almqvist \& Wiksells, 539 p.

Patterson, C. 1968. Menaspis and the bradyodonts. In: T. Ørvig (ed.) Current Problems of Lower Vertebrate Phylogeny. Almqvist \& Wiksells, p. 171-205.

Patterson, C. 1973. Interrelationships of holosteans. In: P.H. Greenwood; R.S. Miles, \& C. Patterson (eds.) Interrelationships of Fishes. Academic Press, p. 233-305.

Roberts, T.R. 1973. Interrelationships of ostariophysans. In: P.H. Greenwood; R.S. Miles, \& C. Patterson (eds.) Interrelationships of Fishes. Academic Press, p. 373-395.

Rosen, D.E. 1973. Interrelationships of higher euteleostean fishes. In: P.H. Greenwood; R.S. Miles, \& C. Patterson (eds.) Interrelationships of Fishes. Academic Press, p. 397-513.

Rosen, D.E.; Forey, P.L.; Gardiner, B. G. \& Patterson, C. 1981. Lungfishes, tetrapods, paleontology, and plesiomorphy. Bulletin of the American Museum of Natural History, 167(4):159-276.

Sahney, S. \& Wilson, M.V.H. 2001. Extrinsic labyrinth infillings imply open endolymphatic ducts in Lower Devonian osteostracans, acanthodians, and putative chondrichthyans. Journal of Vertebrate Paleontology, 21(4):660-669.

Schaeffer, B. 1968. The basic origin and basic radiation of the Osteichthyes. In: T. Ørvig (ed.) Current Problems of Lower Vertebrate Phylogeny. Almqvist \& Wiksells, p. 207-222.

Schaeffer, B. 1973. Interrelationships of chondrosteans. In: P.H. Greenwood; R.S. Miles, \& C. Patterson (eds.) Interrelationships of Fishes. Academic Press, p. 207-226.

Schultze, H.-P. 1993. Patterns of Diversity in the Skull of Jawed Fishes. In: J. Hanken \& B.K. Hall (eds.) The Skull: Patterns of Structural and Systematic Diversity. University of Chicago Press, p. 189-254.

Schultze, H.-P. 1996. Walter R. Gross, a palaeontologist in the turmoil of 20th century Europe. Modern Geology 20 (The Gross Symposium): 209-233.

Schultze, H.-P. \& Cloutier, R. (eds.) 1996. Devonian Fishes and Plants of Miguasha, Quebec, Canada. München, Dr. Friedrich Pfeil, p. 374.

Schultze, H.-P.; Luksevics, E. \& Unwin, D. (eds.) 2003. The Gross Symposium 2: Advances in Palaeoichthyology. Ichthyolith Issues, Special Publication 7:1-59.

Shishkin, M. A. 1973. The morphology of the early Amphibia and some problems of the lower tetrapod evolution. Moscow, NAUKA, 260 p. [in Russian]

Stensiö, E. 1968. The cyclostomes with special reference to the diphyletic origin of the Petromyzontida and Myxinoidea. In: T. Ørvig (ed.) Current Problems of Lower Vertebrate Phylogeny. Almqvist \& Wiksells, p. 13-70.

Thomson, K. S. 1968. A critical review of the diphyletic theory of rhipidistian-amphibian relationships. In: T. Ørvig (ed.) Current Problems of Lower Vertebrate Phylogeny. Almqvist \& Wiksells, p. 285-305.

Turner, S. (ed.) 1995. UNESCO-I.U.G.S. IGCP No. 328 Palaeozoic microvertebrate biochronology and global marine/non-marine correlation 
(1991-1995). State of research 1995. Ichthyolith Issues, Special Publication, 1:1-71.

Turner, S. \& Blieck, A. (eds.) 1996. Gross Symposium. Volume 1. Modern Geology, 20(3-4):203-410.

Turner, S. \& Blieck, A. (eds.) 1997. Gross Symposium. Volume 2. Modern Geology, 21(1-2):1-214.

Valiukevicius, J. 1992. First articulated Poracanthodes from the Lower Devonian of Severnaya Zemlya. In: E. Mark-Kurik (ed.) Fossil fishes as living animals. Academy of Sciences of Estonia, 1:193-213.

Vorobyeva, E. \& Kuznetsov, A. 1992. The locomotor apparatus of Panderichthys rhombolepis (Gross), a supplement to the problem of fish-tetrapod transition. In: E. Mark-Kurik (ed.) Fossil fishes as living animals. Academy of Sciences of Estonia, 1:131-140.

Westoll, T.S. 1943. The origin of the tetrapods. Biological Review, 18:78-98.

Wilson, M.V.H. (ed.) 1997. Circum-Arctic Palaeozoic Vertebrates: Biological and Geological Significance. Ichthyolith Issues, Special Publication, 2:1-39.

Woodward, A. S. 1889. Catalogue of the Fossil Fishes in the British Museum (Natural History). London, British Museum (Natural History), Parts 1-4, 2221 p.

Young, G.C. 1984. Comments on the phylogeny and biogeography of antiarchs (Devonian placoderm fishes), and the use of fossils in biogeography. Proceedings of the Linnean Society of New South Wales, 107(3):443-473.

Young, G.C. 1991. The first armoured agnathan vertebrates from the Devonian of Australia. In: Chang Mee-mann, Liu Yu-hai \& Zhang Guorui (eds) Early Vertebrates and Related Problems of Evolutionary Biology. Beijing, Science Press, p. 67-85.

Young, G.C. \& Moody, J. M. 2002. A Middle-Late Devonian fish fauna from the Sierra de Perijá, western Venezuela, South America. Mitteilungen aus dem Museum für Naturkunde in Berlin, Geowissenschaftliche Reihe 5:155-206.

Zangerl, R. 1968. The morphology and developmental history of the scales of the Paleozoicsharks Holmesella? sp. and Orodus. In: Ørvig, T. (ed.) Current Problems of Lower Vertebrate Phylogeny. Almqvist \& Wiksells, p. 399-412.

Zangerl, R. 1973. Interrelationships of early chondrichthyans. In: P.H. Greenwood; R.S. Miles, \& C. Patterson (eds.) Interrelationships of Fishes. Academic Press, p. 1-14.

Zhu Min \& Schultze, H.-P. 2001. Interrelationships of basal osteichthyans. In: Ahlberg, P. E. (ed.) Major Events in Early Vertebrate Evolution. Palaeontology, phylogeny, genetics and development. Systematics Association Special Volume Series 61:289-314. London and New York, Taylor \& Francis.

Zhu Min, Yu Xiaobo \& Ahlberg, P. 2001. A primitive sarcopterygian fish with an eyestalk. Nature, 410:81-84. 